\title{
Kristinna Andersen og Lisa Balch Christensen Betydningen af lægernes motiver for produktiviteten på de danske sygehuse. Er lægerne aktive med- eller modspillere?
}

Lange ventelister og personalemangel betyder, at der er behov for at forbedre produktiviteten på de danske sygehuse. Spørgsmålet er, om lægernes motiver for udførelsen af deres arbejde hindrer dette. Erfaringer fra Holstebro viser, at læger, der udtrykker samme patient-orienterede motiv som grundlaget for deres arbejde, ikke har samme adfærd i relation til produktivitetsfremmende reformer. Funktionalistisk professionssociologi og rationel neo-weberiansk teori tillægger lægerne henholdsvis altruistiske og egennyttemaksimerende motiver, men begge typer motiver resulterer i samme adfærd, nemlig fravær af produktivitetsforbedringer. Undersøgelser viser, at økonomiske incitamenter kan påvirke lægernes adfærd i relation til opgaver, der ikke er entydigt professionelt definerede. For lægerne i det danske sygehusvæsen er der dog et generelt fravær af klare individuelle og kollektive økonomiske tilskyndelser til at fremme produktiviteten.

Kritikken af det danske sygehusvæsen har været vedholdende de seneste årtier. Fra politisk side har fokus overvejende været rettet mod ventelisteproblematikken, og det seneste eksempel på det er regeringens pulje på 1,5 mia. kr. til sygehusene til nedbringelse af ventelisterne.

Det er dog et åbent spørgsmål, om tilførsel af flere ressourcer alene kan løse sygehusenes ventelisteproblemer. Der kan argumenteres for, at den konstante udvikling i behandlingen af sygdomme vil betyde, at sygehusvæsenet altid vil have brug for flere ressourcer. Dertil kommer, at der allerede nu er mangel på personale blandt læger og sygeplejersker, og at denne personalemangel ikke på det korte sigt kan afhjælpes med tilførsel af ressourcer. En mulig løsning på sygehusenes problemer kan derfor være at skabe øget produktivitet, så de danske sygehuse producerer mere for de ressourcer og det personale, der allerede er til rådighed. Denne problemstilling er udgangspunktet for artiklen, idet artiklen søger at svare på, hvilke muligheder der er for at forbedre sygehusvæsenets produktivitet gennem ændret tilrettelæggelse af arbejdet på sygehusene samt kollektive og individuelle økonomiske incitamenter.

\section{Succes i Holstebro?}

At det kan lade sig gøre at gennemføre interne produktivitetsforbedrende reformer viser et eksempel fra Neurologisk Afdeling, Holstebro Centralsygehus, hvor 1. reservelæge Dorthe Tilsted i efteråret 2001 har formået at afskaffe en venteliste på 160 personer på blot fire måneder. ${ }^{1}$ Det drejede sig om patienter, der var henvist til første undersøgelse i afdelingens ambulatorium. Reduktionen i ventelisten skete alene ved, at Dorthe Tilsted ændrede tilrettelæggelsen af sit eget arbejde. Endringen bestod af flere tiltag. Først undersøgte hun det reelle behandlingsbehov ved at 
verificere, om patienterne stadig havde behov for at blive undersøgt. Dette reducerede ventelisten med 30 pct. Demæst udfyldte hun hulleme i en normal arbejdsdag på flere forskellige måder. Blandt andet ved at indkalde den sidste ambulatoriepatient til kl. 14, mens generel praksis på en normal arbejdsdag, der slutter kl. 15, er at indkalde sidste ambulatoriepatient til kl. 13. Desuden blev patienterne undersøgt både før og efter stuegang, mens lægerne på afdelingen normalt ikke undersøger patienter de dage, de går stuegang. Endelig blev ambulatorietideme ændret således, at der blev afsat en halv, trekvart og en time til undersøgelse efter en konkret vurdering af den enkelte patient modsat normal praksis, hvor der automatisk afsættes en time til hver undersøgelse. Også de medicinstuderende blev brugt mere aktivt i forbindelse med projektet og fungerede i stedet for lægen som forvagt $^{2}$ samtidig med deres almindelige dagarbejde. Alle disse ændringer i tilrettelæggelsen af arbejdet betød, at der kunne undersøges flere patienter, og ventelisten kunne nedbringes.

Dorthe Tilsteds projekt i Holstebro er interessant, fordi det viser, at andre forhold end ressourcetilførsel har betydning for omfanget af ventelisteme. Ved at omlægge arbejdsrutineme og udfylde hulleme $\mathrm{i}$ arbejdsdagen kunne ventelisten afskaffes uden tilførsel af ekstra ressourcer. Projektet viser således, at ændringer af de interne forhold på sygehusene kan bidrage til at løse sygehusenes problemer, og resultatet af projektet er dermed ganske opløftende. Projektet har dog sine begrænsninger som generel løsningsmodel for problememe i sygehusvæsenet. $Æ n-$ dringerne har således alene vedrørt ambulatoriearbejde og en enkelt persons arbejdstilrettelæggelse.

På den anden side burde erfaringeme nemt kunne udbredes til almindeligt ambulatoriearbejde, men projektet i Holstebro viser, at det heller ikke er tilfældet. På trods af den positive effekt af projektet har den administrerende overlæge efter et halvt år ikke taget initiativ til at ændre afdelingens procedurer. Således er erfaringeme ikke blevet udbredt til resten af afdelingen eller sygehuset, og de øvrige læger fortsætter arbejdet ud fra de gamle arbejdsrutiner, blandt andet indkalder man fortsat sidste patient til kl. 13. Eksemplet illustrerer, at der kan gennemføres ændringer, der fremmer sygehusenes produktivitet, men samtidig også at der er en lægelig modstand mod sådanne produktivitetsfremmende tiltag. De berørte læger i casen har således vidt forskellig adfærd i relation til produktivitetsforbedrende reformer. Dorthe Tilsted begrunder sit ventelisteprojekt med, at hun yder patienterne en bedre behandling ved at gennemføre flere undersøgelser. I modsætning til dette pointerer den administrerende overlæge vigtigheden af, at hver enkelt patient tildeles tilstrækkelig undersøgelsestid. Begge læger udtrykker altså, at de vil sikre patienterne den bedst mulige behandling, men den konkrete adfærd er, som det er fremgået, ganske forskellig. Det rejser spørgsmålet om, hvilke motiver der er afgørende for professionelles adfærd, og mere specifikt, hvilke muligheder der er for at ændre adfærden og for eksempel øge produktiviteten i sundhedsvæsenet.

\section{Teoretiske perspektiver på professionelles motiver}

Professionssociologien er et af flere samfundsvidenskabelige perspektiver, der beskæftiger sig med professionelle erhvervsgruppers karakteristika og adfærd 
(Brante, 1988; Brint, 1994; MacDonald, 1995). Den funktionalistiske professionssociologi tillægger de professionelles normer stor betydning. I dette perspektiv er det lægernes pligt at sikre, at hver enkelt patient făr den bedst mulige behandling, hvilket for eksempel kommer til udtryk i det lægeløfte, alle læger skal afgive, før de opnår deres autorisation (Jespersen, 1999: 146; Melander, 1999: 266; Vrangbæk, 1999: 37; Det Danske Lageløfte). Konsekvensen af normen er, at lægerne tilrettelægger deres arbejde på en måde, der optimerer behandlingen af den enkelte patient frem for behandlingen af hele patientgrupper. Ofte vil lægerne opfatte tid som en afgørende faktor for kvalitet $i$ behandlingen, således at jo mere tid lægen har til den enkelte patient, jo bedre behandling er der tale om. Normen om patienthensynet er således umiddelbart en plausibel forklaring på, hvorfor lægerne ikke iværksætter produktivitetsforbedrende ændringer af arbejdstilrettelæggelsen. Lægerne tænker ikke på, og skal ikke tænke på, hvordan de kan optimere deres tidsanvendelse, så de behandler flest mulige patienter med de eksisterende ressourcer. Således også i eksemplet fra Holstebro, hvor der generelt sættes mere tid af til kontrolundersøgelser, selv om undersøgelsen erfaringsmæssigt tager mellem to og 20 minutter med den begrundelse, at det er afgørende for kvaliteten i behandlingen, at patienterne tildeles tid nok. Konsekvensen af denne holdning er imidlertid, at lægerne af hensyn til patienterne ikke optimerer deres tidsanvendelse, hvorved de ikke kan forbedre deres produktivitet.

Lægernes fokus på at yde den enkelte patient optimal behandling er tæt forbundet med normen om, at lægerne ikke skal have økonomiske overvejelser i relation til deres arbejde og deres patienter (Eriksen og Ulrichsen, 1991: 52; Jespersen, 1999: 148; Melander, 1999: 270 ). Konsekvensen af denne norm er også, at lægerne ikke skal forholde sig til, hvordan de kan tilrettelægge arbejdet på den mest produktive måde. Lægerne er og skal kun være interesserede i de lægefaglige aspekter - ikke de økonomiske konsekvenser af arbejdstilrettelæggelsen. Også denne norm udtrykkes af den administrerede overlæge fra Holstebro, der i det hele taget finder det odiøst at betegne lægearbejde som produktion og som logisk konsekvens heraf er kritisk over for den stykprisafregning, der for eksempel er indeholdt i DRG-systemet. ${ }^{3}$ Lægen med ventelisteprojektet er derimod bevidst om økonomiske forhold, hvor hun tydeligt forholder sig kritisk til den eksisterende anvendelse af ressourcerne. En sådan bevidsthed om økonomiske forhold er ikke normen blandt andre læger, for eksempel er der ingen af hendes kolleger på en tidligere arbejdsplads, der anfægtede, at lægernes morgenkonference sluttede kl. 8.15 , hvorefter der var kaffepause til kl. 9.00, hvilket imidlertid samlet set svarede til en hel mistet arbejdsdag.

Lægernes manglende bevidsthed om de økonomiske konsekvenser af arbejdstilrettelæggelsen forstærkes af normen om, at en læge ikke blander sig i en anden læges arbejde (Eriksen og Ulrichsen, 1991: 50, 52). Denne norm gælder både faglige og mere produktivitetsrelaterede spørgsmål. Lægerne samarbejder selvfølgelig omkring lægefaglige problemstillinger, men lægerne udtaler sig ikke uopfordret om andre lægers patienter. Det er endnu mere utænkeligt, at en læge skulle blande sig i, hvor mange patienter en kollega behandler. På Neurologisk Afdeling afspejles normen ved, at det ikke registreres, hvor mange patienter de enkelte læ- 
ger på afdelingen tilser, og selv afdelingsledelsen har ikke data for lægemes produktivitet.

Samlet set kan de tre nævnte normer, der påvirker lægernes holdninger og adfærd, bidrage til at forklare, hvorfor lægerne ikke selv initierer produktivitetsforbedrende reformer. Det er ikke en væsentlig del af lægegerningen at tænke på produktiviteten. Lægerne opfatter selv disse normer som legitime standarder, der medvirker til at sikre kvalitet i lægernes arbejde. Derfor er også konsekvenserne af normerne - fraværet af produktivitetsforbedrende reformer - legitime.

Problemet er imidlertid, at det kan være vanskeligt at sondre mellem, hvornår det er hensynet til den enkelte patient og hensynet til den enkelte læge, der varetages. Overført på Holstebro-eksemplet kan man rejse spørgsmålet, om den administrerende overlæge varetager sine egne eller sine patienternes interesser, når han afviser at ændre tilrettelæggelsen af arbejdet $\mathrm{i}$ ambulatoriet? Og er afvisningen af DRG-systemet og anden aktivitetsrelateret belønning begrundet $i$, at han ikke onsker at arbejde mere, snarere end begrundet $i$ et hensyn til patienterne?

Rationel teori og neo-weberiansk professionssociologi tager udgangspunkt $\mathrm{i}$ en grundlæggende antagelse om, at individer er egennyttemaksimerende (Christensen, 1998b: 196; Collins, 1990). Ud fra denne tankegang kan det være i lægernes interesse at have et arbejde, der er mindst muligt belastende (Migué og Bélanger, 1974: 31-34), og dét, snarere end hensynet til patienter, er årsagen til, at lægeme modsætte sig reformer, der forbedrer produktiviteten. I den neo-weberianske professionssociologi er det grundopfattelsen, at de professionelle normer i første række fungerer som legitimering af monopolet på lægearbejdet. I det perspektiv er de professionelle normer således ikke nødvendige standarder, der sikrer kvalitet $\mathrm{i}$ lægernes arbejde, men et middel til at bevare og beskytte de fordele, der er forbundet med dette monopol (Brante, 1988: 129; Collins, 1990: 35-36). Implikationen af den rationelle og neo-weberianske antagelse om individers egennyttemaksimering er således også et fravær af produktivitetsfremmende reformer.

Funktionalistisk professionssociologi og rationel neo-weberiansk teori tillægger således lægerne forskellige motiver, men begge typer motiver kan resultere i den samme adfærd, nemlig et fravær af og en modstand mod produktivitetsforbedrende reformer. Det betyder, at det kan være vanskeligt at afgøre, hvilken betydning de professionelles motiver har for mulighederne for at gennemfore produktivitetsfremmende reformer. Det er imidlertid ikke nødvendigvis ensbetydende med, at motiverne er uvæsentlige for adfærden. En mulig forklaring på sammenfaldet kunne være, at der ikke er incitamenter til en produktivitetsfremmende adfærd. En måde at nærme sig svaret på spørgsmålet om, hvad der reelt er afgørende for lægernes handlinger, er at undersøge, hvilken betydning økonomiske incitamenter har for lægernes adfærd. Hvis den funktionalistiske fortolkning er rigtig, så skulle incitamenter ikke være afgørende for lægernes adfærd, og ændringer i incitamentstrukturen skulle således ikke ændre adfærden afgørende. Hvis den rationelle neo-weberianske skole er mere rigtig, så vil ændringer i incitamentstrukturen påvirke lægernes adfærd, hvis incitamentstrukturen også påvirker lægernes muligheder for at varetage deres egne interesser. Ved at undersøge lægernes reaktioner på økonomiske incitamenter bliver det muligt at afgøre, hvilke hen- 
syn lægerne varetager. Dermed bliver det muligt at give et bud på, hvordan lægernes adfærd kan påvirkes og ændres.

\section{Litteraturens svar på betydningen af professionelle motiver}

Litteraturen giver flere bud på incitamenters betydning for lægernes adfærd. En undersøgelse af de københavnske praktiserende lægers ændrede overenskomstforhold viste, at de ændrede adfærd, da deres honoreringssystem blev ændret fra en fast aflønning til en honorering af de præsterede ydelser. Efter ændringen i betalingssystemet begyndte de praktiserende læger selv at foretage flere behandlinger, og antallet af henvisninger til hospitaler og speciallæger faldt markant (Krasnik et al., 1990: 1699). Dermed indikerer undersøgelsen, at lægerne påvirkes af individuelle økonomiske incitamenter.

Andre undersøgelser tyder imidlertid på, at det ikke gælder i alle tilfælde. Goodrick og Salanciks (1996) undersøgelse af kejsersnitsfrekvensen på amerikanske hospitaler viser, at økonomiske incitamenter ikke har den store betydning for adfærden, når der er faste professionelle normer for, hvorledes en opgave skal udføres. Derimod viser sygehusets ejerskabsform at have betydning for adfærden i de situationer, hvor der ikke er klart professionelt definerede normer. Undersøgelsen indikerer, at også kollektive økonomiske incitamenter på sygehusniveau i nogen grad kan påvirke adfærden. Betydningen af faste professionelle normer for adfærden hos professionelle støttes af Andersen og Blegvads undersøgelse om børnetandplejen i Danmark (2002), der ligeledes viser, at på områder, hvor der findes faste professionelle normer, så har de økonomiske incitamenter begrænset indflydelse på professionelles adfærd.

Litteraturen kan således tolkes på den måde, at reelle kollektive og individuelle incitamenter i nogen grad kan påvirke lægernes adfærd på områder, hvor der ikke er faste professionelle normer. Implikationen af dette er, at reelle økonomiske incitamenter på såvel kollektivt som individuelt niveau kan anvendes i produktivitetsforbedrende øjemed især på områder, hvor der ikke eksisterer faste normer for udførelsen af arbejdet. Det rejser spørgsmålet om, hvorledes incitamentstrukturen er i det danske sygehusvæsen.

\section{Incitamenterne i det danske sygehusvæsen}

Det overordnede spørgsmål er, om der i det danske sundhedsvæsen er økonomiske incitamenter, der kan påvirke lægernes adfærd. På individniveau har lægerne på de danske sygehuse ingen økonomiske incitamenter til at forbedre produktiviteten, idet de aflønnes uafhængigt af, hvor mange patienter de behandler. Foruden uafhængigheden mellem lægernes normale indkomst og den præsterede aktivitet er der også et generelt fravær af belønning af en eventuel ekstra indsats. For eksempel har overlæger som udgangspunkt ikke overarbejde, og eventuelt overarbejde kan kun udbetales efter særlige aftale med amtet (Indenrigs- og Sundhedsministeriet, 2002b: 22-25).

Det næste spørgsmål er, om der eksisterer incitamenter, der påvirker lægerne som gruppe, dvs. kollektive incitamenter på sygehusafdelingsniveau. De kollektive incitamenter kan overordnet set udformes på to måder. Dels kan aflønningen 
af den enkelte læge afhænge af en afdelings præstationer, og dels kan den enkelte sygehusafdelings ressourcer eller budget være udmålt efter den præsterede aktivitet. I sidstnævnte situation udmøntes belønningen $\mathrm{i}$, at afdelingen kan beholde merindtægten fra en meraktivitet og derigennem udvikle afdelingen for eksempel ved at købe nyt og bedre apparatur. Som før nævnt foregår aflønningen af de danske sygehuslæger uafhængigt af præstationer. Det betyder, at der på de danske sygehuse ikke eksisterer ordninger, hvor en del af lønnen gøres afhængig af afdelingens præstationer. Derimod kan der i et vist omfang identificeres kollektive incitamenter på afdelingsniveau. I 1999 iværksatte en række amter ordninger med aktivitetsbestemt finansiering af behandlingen af amtets egne borgere. Ordningerne indebærer, at en produktion ud over et fastsat niveau honoreres for hver ekstra produceret ydelse, hvor satsen for de enkelte ydelser fastsættes som en procentdel af DRG-værdien. Rationalet bag ordningen er således, at afdelingerne gives incitament til at udnytte deres kapacitet bedre (Indenrigs- og Sundhedsministeriet, 2002a: 31).

Der er dog generelt en række problemer i relation til de amtslige ordninger, som reelt set bevirker, at incitamentet til meraktivitet hos lægerne på de enkelte afdelinger enten er helt fraværende eller $\mathrm{i}$ bedste tilfælde begrænset. For det første er det $\mathrm{i}$ de fleste amter op til sygehusledelsen at afgøre, hvilken andel den producerende afdeling får af merindtægten. Det kan være rimeligt nok, da øget aktivitet på en given afdeling også medfører et øget ressourcetræk på andre afdelinger. I mange tilfælde har det imidlertid betydet, at den udførende afdeling stort set ikke har modtaget nogen belønning for den øgede aktivitet. I flere amter belønnes meraktivitet kun med ti pct. af DRG-værdien, hvorved incitamentet til øget produktion er yderst begrænset. Dertil kommer, at manglen på stabilitet i ordningerne og beløbssatseme for øget aktivitet reducerer lægernes tillid til dem, hvilket også begrænser incitamentet (Christensen, 1998a: 190; Indenrigs- og Sundhedsministeriet, 2002a: 13-14, 35-68). Samlet set har disse forhold betydet, at ordningerne kun rummer begrænsede incitamenter for sygehusafdelingerne til at gennemføre produktivitetsforbedringer.

Regeringsaftalen, hvor sygehusvæsenet samlet tildeles $1,5 \mathrm{mia} . \mathrm{kr}$. til nedbringelse af ventelisterne, er den nyeste ordning, hvor finansiering og aktivitet sammenkædes i sygehusvæsenet. I denne ordning honorerer staten amterne fuldt ud for meraktivitet, når produktionen overstiger et teknisk defineret basisniveau - en såkaldt baseline (Cirkulare om udbetaling af statstilskud $i 2002$ til øget aktivitet på sygehusområdet m.v., 2002a). Ligesom med de amtslige ordninger kan det imidlertid være et problem, at det er op til amterne at fastsætte den udførende afdelings konkrete andel af belønningen for en meraktivitet (Cirkuloere, 2002a). I nogle amter er der fastsat klare fordelingsnøgler mellem de udførende afdelinger og centrale amtslige puljer, mens størrelsen af merindtægten i andre amter fastsættes gennem forhandling med sygehusledelserne (Amtsrådet i Århus Amt, 2002; Sundhedsudvalget i Storstrøms Amt, 2002; Sydvestdansk Formandsforum, 2002). Den store variation i amternes udmøntning af regeringsmidleme betyder, at der ikke er et entydigt billede af incitamentstrukturen i regeringsordningen. I nogle tilfælde er der dog ganske store og faste økonomiske incitamenter for sygehusafde- 
lingerne. De foreløbige opgørelser tyder da også på, at regeringsordningen har haft en vis effekt. Puljen på 1,5 mia. kr. er næsten brugt ved udgangen af 2002, og ventelisterne er på en række områder reduceret betydeligt (Amtsrådsforeningen, 2002, 2003). Spørgsmålet er imidlertid, om det alene kan tilskrives udmøntningen af den statslige pulje på 1,5 mia. $\mathrm{kr}$.

Regeringsaftalen skaber langt fra i alle tilfælde klare og stærke incitamenter for sygehusafdelingerne. Baseline-produktionen beregnes på amtsniveau, hvilket betyder, at hele amtet skal præstere en vis produktion, før der udbetales puljemidler. Sygehusafdelingerne er derfor afhængige af, at alle sygehuse i amtet opfylder deres del af aftalen. Dertil kommer, at beregningsmetoden for baseline er ændret i efteråret 2002 (Cirkulcre om udbetaling af statstilskud i 2002 til oget aktivitet på sygehusområdet m.v., 2002b). Disse elementer af usikkerhed bevirker, at regeringsordningen heller ikke kan karakteriseres som en ordning, der tilvejebringer tydelige incitamenter for lægerne. Reaktionen på regeringsaftalen på Neurologisk Afdeling i Holstebro viser eksempelvis også, at der er behov for at undersøge, om regeringsaftalen medfører reelle produktivitetsforbedringer, eller om der blot er tale om aktivitetsstigninger. Afdelingen skal præstere en aktivitetsstigning på otte pct., før afdelingen når baseline-niveauet og kan få del i puljen. Den administrerende overlæge planlægger at opnå denne produktivitetsstigning ved at ansætte en overlæge i en af tre ubesatte lægestillinger. Dette vil resultere i en forøgelse af aktiviteten, men altså også afdelingens omkostninger.

Samlet set tyder det på, at de økonomiske incitamenter i det danske sygehusvæsen er svage og uklare, hvilket begrænser påvirkningen af sygehusafdelingernes adfærd. Litteraturen indikerer, at der er potentiale $i$ at anvende økonomiske incitamenter som instrument til at forbedre produktiviteten i det danske sundhedsvæsen på områder, hvor de professionelle normer ikke er faste. Det er imidlertid et åbent spørgsmål, i hvilken grad der er indført reelle økonomiske incitamenter i det danske sygehusvæsen, der har effekt på de udførende sygehusafdelinger, eller om der blot er tale om merbevillinger, som omfordeles mellem amts- eller sygehusniveau.

\section{Noter}

1. Interview med 1. reservelæge Dorthe Tilsted og administrerende overlæge Mogens Kjær angående Dorthe Tilsteds ventelisteprojekt på Neurologisk Afdeling, Holstebro Centralsygehus.

2. At være forvagt betyder, at man bærer en personsøger/kalder og er den første læge, der bliver tilkaldt i tilfælde af uventede patienter eller problemer på afdelingen.

3. DRG (Diagnose Relaterede Grupper) er et system til takstfastsættelse af patientforløb. Til hver DRG er der knyttet en omkostningsvægt, som angiver en relativ prisfastsættelse for en given ydelse (Sundhedsstyrelsen, 1999).

\section{Litteratur}

Amtsrådsforeningen (2002). "1,5 mia. puljen: Mange amter får brugt hele deres andel". Pressemeddelelse fra Amtsrådsforeningen 19.11. 
Amtsrådsforeningen (2003). "Nyeste tal fra 1,5 mia. puljen: Amterme bruger flere penge end ventet". Pressemeddelelse fra Amtsrådsforeningen 14.01.

Amtsrådet i Århus Amt (2002). Referat fra møde i amtsrådet i Århus Amt den 05.03.

Andersen, Lotte Bøgh og Marianne Blegvad (2002). Private or Public Service Provision? Economic and Professional Incentives in Danish Dental Care for Children, Arbejdspapir, Arhus: Institut for Statskundskab, Aarhus Universitet.

Brante, Thomas (1988). "Sociological Approaches to the Professions", Acta Sociologica, Vol. 31, No. 2, pp. 119-142.

Brint, Steven (1994). In an Age of Experts. The Changing Role of Professionals in Politics and Public Life, Princeton, NJ: Princeton University Press.

Christensen, Jørgen G. (1998a). "Institutioner, politikere og brugere", pp. 146-193 i Offentligt og effektivt? Institutionelle valg i den offentlige sektor, København: Gyldendal.

Christensen, Jørgen G. (1998b). "Institutionelle valg i den offentlige sektor", pp. 195-230 i Offentligt og effektivt? Institutionelle valg $i$ den offentlige sektor, København: Gyldendal.

Cirkulare om udbetaling af statstilskud i 2002 til oget aktivitet på sygehusområdet m.v. (2002a). Cirkulære nr. 48 af 05.04.

Cirkulare om udbetaling af statstilskud i 2002 til oget aktivitet på sygehusområdet m.v. (2002b). Cirkulære nr. 48 af 14.11.

Collins, Randall (1990). "Marked Closure and the Conflict Theory of the Professions",pp. 24-43 in Michael Burrage and Rolf Torstendahl (eds.), Professions in Theory and History. Rethinking the Study of the Professions, London, Newbury Park, New Delhi: Sage Publications.

Det Danske Lagelofte. www.dadlnet.dk/2laegeforeningen/retogetik/vejledninger/etik/legeloftet.htm

Eriksen, Henrik og Helle Ulrichsen (1991). Tre kulturer i hospitalssektoren. Sygepleje-, administrations- og lagesøjlen. København: Handelshøjskolens Forlag.

Goodrick, Elizabeth and Gerald R. Salancik (1996). "Organizational Discretion in Responding to Institutional Practices: Hospitals and Cesarean Births", Administrative Science Quarterly, Vol. 41, pp. 1-28.

Indenrigs- og Sundhedsministeriet (2002a). Aktivitetshestemt finansiering i Danmark. Foreløbige erfaringer, København: Statens Information.

Indenrigs- og Sundhedsministeriet (2002b). Barrierer for mere effektiv arbejdstilrettelaggelse på sy'gehusene, København: Statens Information.

Indenrigs- og sundhedsministeriet (2003). Takststyring på sygehusområdet, København: Statens Information.

Jespersen, K. Peter (1999). "New Public Management reformers betydning for den administrative og lægefaglige profession i sygehusorganisation", pp. 143-169 i Eva Z. Bentsen et al. (red.), Når styringsambitioner moder praksis. Den svare omstilling af sygehus- og sundhedsvasenet i Danmark og Sverige, København: Handelshøjskolens Forlag.

Krasnik, Allan et al. (1990). "Changing Remuneration Systems: Effects on Activity in General Practice", British Medical Journal, Vol. 300, pp. 1698-1701.

MacDonald, Keith M. (1995). The Sociologv of The Professions, London: Sage Publications.

Melander, Preben (1999). "Økonomistyring og organisatorisk skizofreni - om fattige sprog, løse koblinger og onde cirkler”, pp. 265-290 i Eva Z. Bentsen et al. (red.), Når styringsambitioner moder praksis. Den svare omstilling af sygehus-og sundhedsvasenet i Danmark og Sverige, København: Handelshøjskolens Forlag.

Migué, Jean-Luc and Gérard Bélanger (1974). "Toward a General Theory of Managerial Discretion", Public Choice, Vol. 17, pp. 27-43.

Sundhedsstyrelsen (1999). Specialespecifikkekode-og registreringsvejledninger, version 1.1, Kontor for Medicinsk Informatik.

Sundhedsudvalget i Storstrøms Amt (2002). Referat fra møde i Sundhedsudvalget i Storstrøms Amt 05.03.

Sydvestdansk Formandsforum (2002). Referat fra møde i Sydvestdansk Formandsforum 11.04. 
Vrangbæk, Karsten (1999). 'Når styringsideer og modeller udfordrer sundheds- og sygehusfeltets logikker", pp. 33-56 i Eva Z. Bentsen et al. (red.), Når sturingsambitioner moder praksis. Den svaere omstilling af sygehus- og sundhedsvoesenet i Danmark og Sverige, København: Handelshøjskolens Forlag. 